\title{
PERANCANGAN LOGO ORGANISASI FORUM KOMUNIKASI MASYARAKAT PEDULI DIFABEL (FKMPD) KLATEN
}

\author{
Ariefika Listya, Angga Kusuma Dawami \\ Universitas Indraprasta PGRI \\ ariefika.listya@unindra.ac.id ; akdawami@gmail.com
}

\begin{abstract}
Abstrak
Tidak hanya organisasi berorientasi profit, organisasi non profit juga memerlukan logo, agar dapat membedakan dirinya dengan entitas organisasi yang lain. Ketidakadaan identitas visual salah satu organisasi difabel di Klaten Forum Komunikasi Masyarakat Peduli Difabel (FKMPD), menyebabkan persepsi masyarakat kepada organisasi tersebut hanya sebatas ada kegiatan, namun tidak terposisikan dengan baik dalam benak komunitas lain yang lebih luas. Studi ini membahas tentang bagaimana merancang logo dan implementasinya pada beberapa media secara konsisten sesuai dengan identitas dari entitas Forum Komunikasi Masyarakat Peduli Difabel (FKMPD) Klaten. Dengan menggunakan metode deskriptif kualitatif, tulisan ini memberikan gambaran bahwa merancang logo organisasi non profit terkait difabel khususnya FKMPD memerlukan proses yang sama dengan merancang logo organisasi berorientasi profit pada umumnya. Penelitian berbasis perancangan ini menghasilkan logo FKMPD Klaten yang bertipe logotype guna menekankan nama FKMPD dimana huruf K merupakan representasi ikon orang yang bersemangat dan penuh harapan serta huruf $\mathrm{M}$ yang merupakan penggabungan dari simbol hati merepresentasikan wujud kepedulian terhadap kesetaraan difabel dengan non difabel.
\end{abstract}

Keywords: Logo, Difabel, Organisasi Non Profit, Komunikasi Visual

\begin{abstract}
As well as profit organizations need a logo, so do non profit organizations to be differentiate from others. Inexistence of visual identity of non profit organization focusing on different ability named Forum Komunikasi Masyarakat Peduli Difabel (FKMPD) Klaten causing the public perception of its organization to be limited to just doing activities, but not well positioned in the minds of other communities. This paper discusses how to design the logo and its implementation on various media consistently in accordance to the identity of FKMPD Klaten. By using qualitative descriptive method, this study gives an insight that designing the logo of non-profit organization related to different ability people especially FKMPD Klaten require the same process as designing the logo of profit organization in general. This design-based research generates the type of logo design of FKMPD Klaten is logotype to emphasize the name of FKMPD where the " $K$ " letter represents the icon of a passionate and hopeful person and the " $M$ " letter which is incorporated the heart symbol represents a manifestation of concerning equality of disabled people with non-disabled people.
\end{abstract}

Keywords: Logo, Disabled People, Non profit organization, Visual Communication 


\section{PENDAHULUAN}

Penyandang Disabilitas atau lebih banyak dikenalkan dengan nama Difabel dari kepanjangan Different Ability People, memiliki daya juang dari sebelum adanya Undang-Undang (UU) nomor 4 tahun 1997 tentang Penyandang Cacat untuk memenuhi kebutuhan haknya akan pelayanan publik. Pelbagai langkah advokasi terus menerus dilakukan agar terciptanya kesetaraan dalam menjalani kehidupan antara Difabel dengan NonDifabel. Kasus-kasus marginalisasi Difabel secara personal semakin membuat Difabel tidak memiliki posisi tawar di masyarakat. Kemudian muncul perkumpulan-perkumpulan yang berbasis organisasi maupun komunitas Difabel di masyarakat yang memperjuangkan hakhak Difabel untuk diakui dan direalisasi sesuai dengan UU no. 8 tahun 2016 tentang Penyandang Disabilitas. Peraturan Undang-Undang ini menjadi semangat baru untuk organisasiorganisasi difabel diberbagai tingkat di Indonesia untuk membentuk posisinya sebagai bagian dari masyarakat yang seharusnya dimasyarakatkan, melalui advokasi.

Langkah-langkah advokasi secara aktif dilakukan oleh organisasi dan kelompok Difabel di berbagai tingkat melalui kelompoknya, dengan partisipasi aktif dalam kegiatan Pemerintah maupun non-Pemerintah. Salah satunya adalah Forum Komunikasi Masyarakat Peduli Difabel (FKMPD) Kab. Klaten. Tujuannya adalah mendapatkan kesetaraan di segala bidang di masyarakat. Mulai dari Nasional, Regional, sampai kepada tingkat akar rumput di Desa. Pada tingkat Nasional ada Gerakan Kesejahteraan Tuna Rungu dan Tuna Wicara Indonesia (GERKATIN), Persatuan Tuna Netra Indonesia (PERTUNI), dan organisasi Difabel nasional lain. Advokasi oleh kelompok-kelompok Difabel ini juga dikonfirmasi oleh Pemerintah melalui turunan UU no. 4 tahun 1997 tentang Penyandang Cacat yang diganti UU no. 8 tahun 2016 tentang Penyandang Disabilitas, berupa peraturan di tingkat kota/kabupaten seperti Peraturan Daerah (Perda) Kota Surakarta no. 2 tahun 2008 tentang Kesetaraan Difabel atau Perda Kabupaten Karanganyar no. 6 tahun 2014 tentang Kesetaraan Difabel.

Munculnya UU no. 8 tahun 2016 tentang Penyandang Disabilitas, organisasi-organisasi difabel dipelbagai tingkat semakin gencar untuk membentuk kebutuhan dirinya akan aksesibilitas, dan meneruskan eksistensi dirinya sebagai salah satu sendi masyarakat yang kurang diperhatikan, serta terus memperjuangkan untuk mendapatkan haknya. Setiap organisasi difabel berusaha semaksimal mungkin untuk melakukan hal tersebut, seperti PERTUNI yang memperjuangkan guiding block di trotoar dan fasilitas umum agar mereka dapat mandiri dalam berjalan. GERKATIN yang terus memperjuangkan Bahasa Isyarat Indonesia (BISINDO) agar menjadi bahasa yang diakui oleh negara sebagai bahasa komunikasi resmi menggantikan Sistem Isyarat Bahasa Isyarat (SIBI) yang dibuat oleh pemerintah. PPCK yang memperjuangkan untuk dibuatkan aksesibilitas terhadap fasilitas-fasilitas umum agar sesuai dengan kemampuan mereka dalam menjangkaunya, seperti disediakan RAMP (bidang landai yang memiliki kemiringan tidak lebih dari 30 derajat agar dapat dilewati kursi roda).

Pada dasarnya setiap entitas organisasi difabel tidak bisa lepas dari kewajiban dirinya untuk mengenalkan dirinya kepada masyarakat. Kebutuhan pengenalan diri organisasi difabel di tingkat desa, terkadang menjadi hal yang tidak perhatikan, disamping pekerjaanpekerjaan lapangan yang memang harus 
dilakukan, seperti: menguatkan jaringan antar organisasi difabel, membangun komunikasi efektif dengan pemerintah desa, bahkan membuat posisi tawar di tingkat kota/kabupaten, maupun di tingkat nasional. Komunikasi visual yang seharusnya mendukung posisi tawar organisasi difabel, akhirnya tidak didapatkan, karena bentuk-bentuk komunikasi visual yang khas, seperti bentuk logo yang tidak diperhatikan dan asal dibuat sebagai sebuah syarat.

Dalam organisasi difabel, terutama di desa, peran logo dianggap sebagai tambahan, dan penghias kertas undangan pertemuan saja. Padahal logo menjadi salah satu komponen komunikasi visual yang banyak digunakan oleh entitas besar untuk membentuk posisi tawarnya. Merek atau brand inilah yang menjadikan masyarakat memahami sesuatu karena ide-ide dari entitas melekat pada masyarakat yang menjadi sasaran visual dari logo. Secara sederhana, bagaimana sebuah organisasi difabel dapat dikenal di masyarakat, kalau secara visual kurang dikenal dan dipahami oleh masyarakat. Dalam skala organisasi difabel di tingkat nasional, provinsi, atau kota/kabupaten, logo satu organisasi difabel satu dengan yang lain, pasti berbeda, dan memiliki makna sesuai dengan entitas organisasi difabel masing-masing.Perwujudan logo difabel juga menjadi identitas untuk mengenalkan dirinya kepada masyarakat sekitarnya yang setiap hari berkomunikasi dengan difabel di manapun, bahkan di desa.

FKMPD adalah Organisasi tingkat

Kabupaten yang bergerak dalam isu Advokasi untuk Anak dan Perempuan di wilayah Klaten. Pembentukan Organisasi FKMPD berdampak langsung terhadap difabel perempuan dan anak di wilayah kecamatan Klaten Tengah, Ceper, Trucuk, dan Ngawen. Masing-masing FKMPD bergerak sesuai dengan visi dan misi masing-masing. Inisiasi untuk menggabungkan FKMPD menjadikan FKMPD bersatu dan membentuk entitas besar FKMPD tingkat Kabupaten Klaten. Penawaran dari tim Abdimas DKV Unindra untuk membuat Logo FKMPD memberikan arah positif untuk pembuatan logo FKMPD yang baru. Pembuatan logo untuk sebuah organisasi difabel akan lebih bermanfaat apabila tidak hanya meniru organisasi difabel lain. Seperti visual kursi roda misalkan, hampir semua organisasi difabel daksa tingkat nasional ataupun tingkat daerah memiliki kursi roda dalamnya. Beberapa organisasi difabel yang lain identitas visual hanya berdasar pada tulisan saja, belum sampai memikirkan bagaimana dampak kedepan logo tersebut dibuat. Dalam rangka membantu menguatkan sistem informasi di desa, maka dibutuhkan sebuah tulisan yang menerangkan bagaimana membuat logo organisasi difabel di desa yang dapat mengangkat merek serta komunikasi visual yang baik.

Tulisan ini membahas tentang bagaimana membuat logo organisasi difabel Forum Komunikasi Masyarakat Peduli Difabel (FKMPD) yang memenuhi standar komunikasi visual. Tujuannya adalah sebagai referensi membuat dan membentuk logo yang memiliki konsistensi merek di tingkat kabupaten maupun ditingkat desa, agar konsistensi merek tentang organisasi difabel di desa tetap terjaga. Di sisi lain, posisi tawar FKMPD dapat setara dengan organisasi non-difabel lainnya.

\section{PEMBAHASAN}

\section{Logo sebagai identitas visual organisasi non profit}

Penelitian mengenai tinjauan maupun penciptaan desain identitas visual bagi organisasi non profit masih terbatas. Van den Bosch, De Jong, dan Elving (2006) meneliti perbedaan 
identitas visual antara perusahaan produk dengan jasa dan organisasi berorientasi profit dengan organisasi non profit. Dalam menganalisis digunakan teori CVI (Corporate Visual Identity) atau identitas visual korporat baik organisasi berorientasi profit dengan organisasi non profit. Seperti yang diketahui, secara harafiah kata "corporate" berarti perusahaan, namun tidak terbatas hanya entitas berupa perusahaan melainkan juga organisasi. Organisasi yang dimaksud juga tidak terbatas pada yang berorientasi profit melainkan juga non profit. Pemahaman tersebut mengarahkan kepada asumsi bahwa dalam merancang identitas visual organisasi non profit sama halnya dengan merancang identitas perusahaan atau organisasi berorientasi profit sehingga proses dan tahapan merancang identitas visual FKMPD Klaten akan sama dengan merancang identitas visual pada umumnya. Hal ini juga dilakukan agar konsep inklusi itu masuk dalam pembuatan logo yang tidak diskriminatif.

Sebuah perusahaan tanpa logo tidak dapat membuat dampak pada target audiens-nya, dan logo membantu mengkomunikasikannya:

An enterprise without a logo has no chance of making an impact on its target audience. You have to be seen to be heard. Logos help to communicate with the target audience and are often the first point of contact with that group, (Hardy, 2011, p. 3)

Dilanjutkan oleh Hardy bahwa logo merupakan pengidentifikasi berupa gambar yang berguna untuk mengkomunikasikan apapun yang diperlukan agar dikenal:

A logo is a graphic identifier that is used to visually communicate anything that requires to be identified. It helps the brand set itself apart from the competition- you don't see the Golden Arches and think of Burger King. And yet logos are not limited to commercial endeavors-charitable

organizations, campaigns, even individuals can use logos to identify themselves (Hardy, 2011, p. 3).

Logo adalah sebuah ikon visual yang memberikan dua fungsi dasar bagi merek yaitu identifikasi dan diferensiasi. Ada beberapa tipe logo yang dibuat dari nama perusahaan, disajikan dalam bentuk unik, sampai dengan yang abstrak yang mungkin tidak ada hubungannya secara langsung dengan nama perusahaan maupun aktivitasnya (Farhana, 2012). Jika jenis huruf telah digunakan dalam sebuah logo, maka huruf tersebut akan sering dikombinasikan dengan gambar. Saat memadukannya dengan gambar atau ilustrasi, sebaiknya saling melengkapi atau berlawanan namun harus selalu berhierarki visual dan mempunyai keseimbangan secara keseluruhan (Krause dalam Kirk, 2013:6).

Identitas visual korporat memainkan peran yang signifikan dalam mempresentasikan organisasi kepada pihak stakeholder secara internal maupun internal (van de Bosch, de Jong \& Elving, 2006:138). Pentingnya identitas visual korporat bagi suatu organisasi biasanya dilihat dalam hubungannya dengan identitas, citra dan reputasinya. Dalam identitas visual diperlukan adanya konsistensi pada implementasinya di berbagai media. Terlalu banyak variasi visual akan mengakibatkan ketidakfokusan pada impresi (Van de Bosch, de Jong \& Elving, 2006:140)

Dalam menciptakan konsistensi visual diperlukan kesatuan antar elemenelemen identitas visual, termasuk gaya grafis. Gaya grafis khas menurut Listya ( 2016: 116) merupakan bagian dari identitas visual korporat yang penting karena fungsi gaya grafis khas dalam 
media selain sebagai hiasan adalah sebagai penguat identitas.

Identitas visual korporat merupakan ranah Desain Komunikasi Visual, dimana Desain Komunikasi Visual memiliki tiga fungsi dasar yaitu sebagai sarana identifikasi, sebagai sarana informasi dan instruksi, dan yang terakhir sebagai sarana presentasi dan promosi (Cenadi, 1999:4).

Penelitian mengenai identitas visual bagi organisasi non profit yang fokus pada difabel nampaknya belum ada. Penelitian terkait difabel pernah dilakukan oleh Bonardo (2015:77) mengenai tayangan Hitam Putih trans7 dalam tesisnya dimana ditemukan bahwa bahasan mengenai difabel jika semula hanya dalam medium tradisional, kini telah berkembang menjadi media massa. Sehingga dapat disimpulkan oleh Bonardo bahwa disabilitas menjadi semakin masif dimarginalisasi. Meski penelitian tersebut tidak membahas mengenai identitas visual difabel, peneliti berasumsi bahwa sebaiknya dalam membuat identitas visual yang nantinya akan dilihat secara massal oleh masyarakat justru menghindari elemen visual yang dapat memarjinalisasikan difabel. Disamping itu, pembuatan logo organisasi difabel yang akan dibuat ini dalam penjelasan sub-bab selanjutkan akan dijelaskan bahwa tujuannya adalah dalam rangka mendukung advokasi aagar difabel setara dengan non difabel.

\section{Profil dan kegiatan FKMPD Klaten}

Pembuatan logo yang dapat merepresentasikan sebuah kelompok difabel tidak sertamerta muncul hanya karena kebutuhan dalam persyaratan administratif organisasi saja. Namun juga dapat memberikan gambaran, tentang bagaimana organisasi difabel ini tumbuh dan berkembang di desa. Hal yang harus dilakukan ketika melakukan perancangan logo adalah menggali identitas entitas yang akan dibuat logonya.

Profil FKMPD Klaten

FKMPD (Forum Komunikasi

Masyarakat Peduli Difabel) Klaten didirikan atas inisiasi difabel dan orangtua difabel yang difasilitasi oleh sebuah LSM yakni PPRBM Solo (Pusat Pengembangan dan Pelatihan Rehabilitasi Bersumber daya Masyarakat). Awalnya PPRBM merupakan organisasi sayap dari Yayasan Pembinaan Anak Cacat (YPAC) Kota Surakarta, namun telah memisahkan diri dan mendirikan Pusat Pelatihan untuk orang-orang difabel secara umum berdasarkan pada sumberdaya masyarakat yang ada. Pada dasarnya, YPAC mengabdikan baktinya untuk membina anak-anak berkebutuhan khusus, melalui bantuan terapi serta pendidikan formal dan non formal yang disesuaikan dengan keadaan masingmasing. Mereka masih dapat menikmati hidup yang berkualitas meskipun tidak sempurna. Dengan pembinaan ini, kami menyiapkan mereka agar tetap dapat hidup sebagai anggota masyarakat yang berguna di kemudian hari. Tujuannya adalah membentuk masyarakat yang terlatih untuk memandirikan difabel, tumbuh bersama difabel, dan berkegiatan bersama dengan difabel, layaknya masyarakat pada umumnya. Alasannya jelas bahwa banyak difabel yang saat ini dikucilkan karena memang dipandang tidak mampu, atau terasa kasihan saja. PPRBM mengembangkan konsepsi dari YPAC untuk memberikan fasilitas pelatihan yang tidak hanya untuk anak difabel, namun juga difabel di masyarakat secara umum. PPRBM akhirnya berinisiasi untuk membantu membangun FKMPD dikarenakan beberapa alasan, yaitu: 
1. Faktor internal:

a. Belum tertampungnya aspirasi difabel dalam kebijakan pemerintah daerah.

b. Belum ada wadah bagi difabel untuk menampung segala permasalahan dan potensi yang ada.

c. Menyatukan aspirasi dan kebutuhan difabel, dalam rangka mencapai perubahan dari aspek pendidikan, kesehatan, sosial budaya, ekonomi, partisipasi, keadilan hukum dan lainnya.

d. Kesadaran kritis difabel dan keluarga difabel masih rendah.

e. Kurangnya kebersamaan dan kekompakan para difabel.

f. Kurangnya informasi dan pemanfaatan akses jaringan bagi difabel.

2. Faktor Eksternal:

a. Program pemerintah terkadang tidak sesuai dengan kebutuhan difabel.

b. Kebijakan pemerintah yang terkadang tidak berpihak pada difabel.

c. Kurangnya pendampingan dan pembinaan intensif kepada difabel.

\section{Kegiatan FKMPD Klaten}

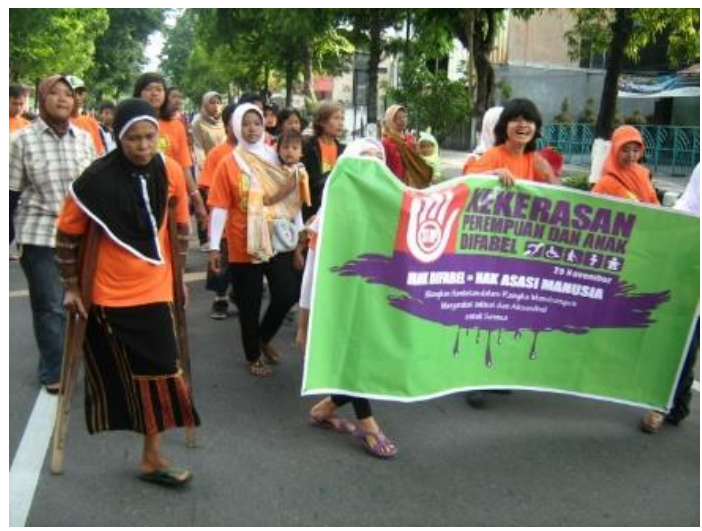

Gambar 1. Aksi saat Hari Disabilitas Internasional

Aksi untuk mengurangi stigma dan diskriminasi dilakukan oleh FKMPD sebagai usaha advokasi. Tujuannya adalah membentuk persepsi masyarakat bahwa difabel dapat melakukan apa yang orang non-difabel lakukan, seperti menyuarakan haknya sebagai warga masyarakat yang setara dan tidak diskriminatif.

Hal ini dilakukan untuk membentuk persepsi masyarakat, bahwa bukan hanya masyarakat non-difabel saja yang dapat melakukan aksi untuk mengangkat sebuah isu, namun juga kawan-kawan difabel mampu untuk membuat aksi guna mengubah persepsi masyarakat tentang difabel. Banyak masyakarat yang masih memandang bahwa difabel itu lemah, harus dikasihani, dan dibantu dengan uang saja. Padahal banyak difabel yang sudah mulai mapan dengan usahanya, memiliki pekerjaan sebagai abdi negara, atau pekerjaan yang menjamin kehidupannya mendatang. FKMPD berusaha untuk mewadahi masyarakat difabel maupun non-difabel yang ingin berkontribusi untuk membenarkan konstruksi berfikir masyarakat non-difabel terhadap difabel itu sendiri melalui aksi-aksi yang dapat mengurangi stigma dan diskriminasi bagi orang difabel.

Jaringan terhadap organisasiorganisasi difabel lain membuat FKMPD menjadi salah satu wadah untuk menyalurkan alat bantu untuk difabel yang membutuhkannya. Akses terhadap alat bantu terus menerus dilakukan agar aksesibilitas difabel dapat terwujud.

Fasilitasisasi terhadap aksesibilitas difabel di internal FKMPD ataupun di sekitar Klaten menjadi sebuah tanggungjawab moral yang harus terus dilakukan FKMPD agar kualitas hidup difabel di Klaten terus meningkat. Pengembangan jaringan, pembentukan stakeholder yang sadar tentang isu difabilitas di tingkat desa/kelurahan, maupun kecamatan terus menerus dilakukan agar aksesibilitas terus 
diadakan oleh Pemerintah Kabupaten Klaten, maupaun masyarakat Klaten guna membangun pandangan positif terhadap difabel di Klaten. FKMPD juga melakukan pelatihan-pelatihan terkait dengan sensitifitas difabel di tingkat desa/kelurahan, kecamatan guna membangun kebijakan pemerintah yang pro-difabel. Selain itu, penyadaran melalui organisasi-organisasi masyarakat di sekitar FKMPD menjadi ujung tombak untuk melakukan advokasi, seperti sosialisasi di PKK, Karang Taruna, dan Kelompok-kelompok Pengajian terus menerus dilakukan.

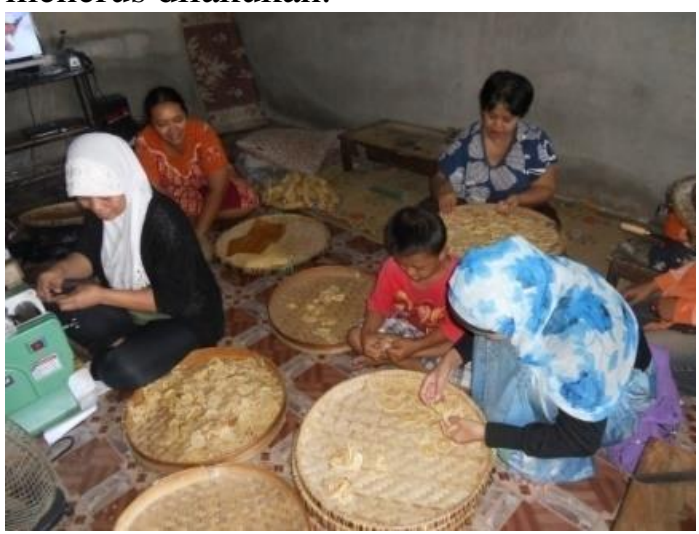

Gambar 2. Usaha Produksi Makanan

Perjuangan FKMPD tidak hanya mengusahakan terhadap luar jaringan dari FKMPD, seperti pemerintah dan masyarakat. Pengembangan kemandirian terus dirintis, melalui konsep Kemandirian Diri oleh FKMPD. FKMPD tidak hanya berkutat pada advokasi tingkat pemerintah saja, namun juga berjuang untuk memandirikan difabel, agar kesiapan hidup difabel di masyarakat juga dapat terpenuhi. Tidak hanya sebagai keinginan FKMPD saja, namun juga difabel yang tergabung di FKMPD dapat berbaur, berkegiatan, berusaha bersama dengan masyarakat menuju masyarakat inklusif.

Salah satu usaha yang dilakukan oleh FKMPD adalah membuat pos-pos produksi untuk dapat menjadi produk yang siap jual, menjadikan FKMPD memiliki kekuatan ekonomi mikro yang dapat mendukung pergerakan organisasi.
Selain menyiapkan difabel itu sendiri terhadap masyarakat sekitarnya, FKMPD juga memiliki tanggungjawab untuk mengembangkan organisasi sebagai sebuah institusi, semangat perjuangan, dan tujuan besar difabel sesuai dengan UNCRPD. Maka, kemandirian difabel sangat diperlukan untuk membentuk persepsi difabel, bahwa difabel dapat melakukan hal-hal yang biasa dilakukan oleh orang-orang non difabel di sekitarnya. Hal ini menjadi sebuah pembuktian bahwa difabel tidak hanya meminta, atau sekedar memberikan pembuktian minimal. Kemandiri difabel akan dilihat sebagai sebuah usaha nyata untuk membuat masyarkat di sekitarnya percaya, bahwa difabel itu mampu mandiri. Tidak hanyan perlu dikasihani saja, namun juga dibantu untuk bangun bersama terkait dengan kehidupan masyarakatnya. FKMPD bertujuan untuk hal tersebut.

\section{METODE PERANCANGAN}

\section{Focus group discussion (FGD)}

Focus Group Disscusion (FGD) kepada para anggota kelompok untuk mengetahui identitas dan programprogram kegiatan guna mendapatkan gambaran kebutuhan mitra sehingga produk yang diciptakan dapat memberikan manfaat dan solusi yang tepat.

Metode pelaksanaan dengan cara observasi yaitu merumuskan bersama dengan pihak Forum Komunikasi Masyarakat Peduli Difabel (FKMPD) di Klaten berupa:

1. Brainstroming ide dan diskusi untuk Logo Difabel FKMPD

2. Penentuan obyek-obyek kunci visual untuk perluasan ide

3. Perancangan Alternatif Logo

4. Konsultasi untuk menentukan logo yang akan digunakan 
5. Perancangan Logo Final dan media aplikasikasinya

6. Menyerahkan hasil perancangan kepada FKMPD

\section{Tahapan perancangan}

1. Menggali informasi dan insight dari stakeholder (pemangku kepentingan) yang ada di FKMPD, berdiskusi dengan anggota kelompok FKMPD melalui Focus Group Discussion (FGD), kemudian membuat creative brief guna mendapatkan konsep komprehensif yang sesuai dengan karakter logo yang dibuat. Pada tahap ini banyak masukan, banyak kontruksi pikiran yang ingin ditungkan dalam sebuah logo, sesuai dengan kondisi, visi-misi, dan keadaan FKMPD sekarang. Kecenderungan terhadap logo-logo yang bersifat difabelistik, seperti alat bantu, kursi roda, dan lain sebagainya tetap muncul. Pada FGD dengan FKMPD didapatkan beberapa keinginan dalam logo FKMPD:

a. FKMPD pakai uppercase alias huruf besar semua untuk mewakili inisial nama forumnya.

b. Huruf $M$ yang berbentuk tangan merepresentasikan 3 kalangan: wanita, anak dan lansia, dan menyimbolkan kasih sayang serta kepedulian yang tinggi.

c. Warna yang mewakili semangat FKMPD dalam memperjuangkan difabel untuk mengurangi stigma dan diskriminasi agar setara dengan yang lainnya

Keinginan-keinginan dari FKMPD menjadi pertimbangan untuk tim pembuat logo dalam membentuk logo yang sesuai dengan konsep logo yang dibuat. Perancangan ini tidak hanya sebatas dari pandangan pembuat, namun juga melihat dari hasil diskusi yang telah ditetapkan.
Namun, konsep yang disepakati bersama adalah sama. Membentuk logo yang mencerminkan FKMPD sebagai sebuah organiasasi yang mewakili difabel Klaten dalam berjuang untuk perempuan dan anak difabel di Kabupaten Klaten.

2. Mengidentifikasi Logo komunitas dan organisasi difabel lainnya
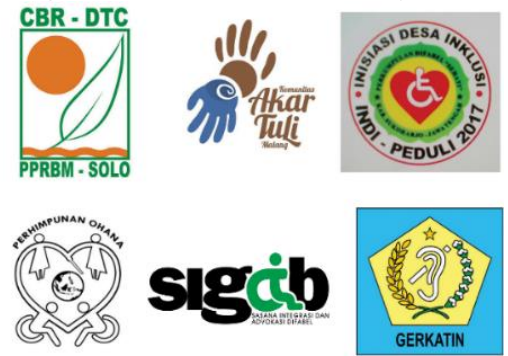

Gambar 3. Logo komunitas dan organisasi difabel lainnya

Guna mendapatkan logo yang komprehensif, maka tim pembuat logo, mengoleksi logo yang berdekatan secara geografis dengan FKMPD disekitar Karesidenan Surakarta dan Yogyakarta. Dari koleksi logo yang ada di sekitarnya, empat dari enam logo organisasi peduli difabel yang sudah ada menggunakan simbol yang berkaitan dengan difabel berupa figur masusia pada kursi roda dan ikon telinga yakni logo Inisiasi Desa Inklusi, logo Perhimpunan Ohana, logo Sasana Integrasi dan Advokasi Difabel, dan Logo Gerkatin. Dua dari enam organisasi yaitu CBR DTC dan Komunitas Akar Tuli Malang tidak memakai simbol terkait difabel melainkan objek figuratif yang nampaknya menunjukkan "kasih sayang", "harapan", dan "kepedulian" dengan memvisualisasikan sebuah tangan, daun, matahari bahkan bunga. Konsep "kasih sayang", "harapan", dan "kepedulian" pada beberapa dari keenam logo diatas nampaknya sudah mewakili apa yang diharapkan oleh 
organisasi difabel. Identitas visual logo FKMPD akan diupayakan berbeda dengan keenam logo ini agar identitasnya kuat, sesuai dengan tujuan besar FKMPD, yaitu mencapai kesetaraan difabel dengan non- difabel, terutama perempuan dan anak difabel.

3. Pembuatan creative brief secara sederhana seperti perancangan logo pada umumnya untuk memudahkan hasil brainstorming:Tabel 1. Creative Brief

\begin{tabular}{cl}
\hline Entity & Forum yang bergerak di bidang sosial kemanusiaan. \\
& Nama entitas : FKMPD Klaten (Forum Komunikasi Masyarakat \\
& Peduli Difabel Klaten). \\
Description & FKMPD Klaten berusaha untuk mencapai kesetaraan dengan \\
& non difabel lain dengan cara mengurangi stigma negatif dan \\
& diskriminasi yang diterima oleh difabel perempuan dan anak di \\
& wilayah anggotanya masing-masing. \\
Problem & FKMPD Klaten belum memiliki logo sebelumnya, sehingga \\
& diperlukan logo yang dapat merepresentasikan identitas mereka \\
Objective & Untuk mengenalkan identitas dan citra kepada masyarakat \\
& mengenai FKMPD Klaten dan semangat untuk \\
& memperjuangkan hak-hak difabel sesuai dengan amanat CRPD \\
dan UU no. 8 tahun 2016 tentang Penyandang Disabilitas \\
Target Market & $\begin{array}{l}\text { Pria dan wanita, usia remaja dan dewasa, wilayah Klaten } \\
\text { maupun diluar klaten, mereka yang memiliki kepedulian sosial }\end{array}$ \\
& terhadap difabel \\
Manner & Semangat, harapan dan kepedulian \\
What to do & Mendesain logo baru dan implementasinya pada beberapa \\
& media \\
A must & Mengandung warna merah, Tidak menggunakan emblem pada \\
& logo
\end{tabular}

4. Menentukan konsep logo, dimana konsep logo yang ditawarkan adalah menitikberatkan pada semangat dan kepedulian FKMPD Klaten untuk menyetarakan difabel Klaten dengan non-difabel untuk desain logonya, karena nama forumnya sudah mengandung kata difabel maka tidak menggunakan simbol-simbol difabel. Disamping itu, simbol difabel juga sudah banyak digunakan oleh entitas lainnya, hal ini yang membedakan dirinya dengan organisasi difabel lain. Dimana semangat menjadi unsur utama dalam membentuk jejaring yang kuat untuk melakukan advokasi efektif.

5. Brainstorming untuk menentukan keyword, membuat mindmapping dan thumbnail sketch. Langkah ini adalah langkah inti untuk penggalian ide dalam memahami FKMPD secara holistik dan fundamen. Sehingga logo yang tercipta tidak asal jadi, dan kurang merepresentasikan dari identitas FKMPD itu sendiri. Hal ini akan mengurangi resiko logo hanya akan digunakan sebagai administratif saja, namun juga memberikan pandangan baru terhadap FKMPD yang terpresentasi dari logonya.

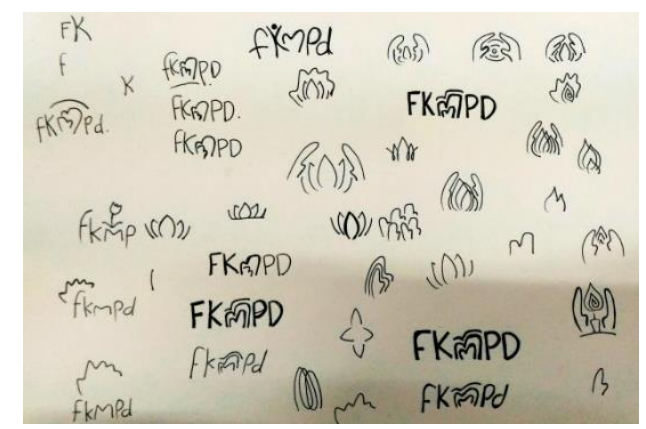

Gambar 4. Membuat Sketsa dan Draft Logo yang akan menjadi Logo utama 
6. Terpilih beberapa alternatif logo, kemudian dibuat computerized kemudian memilih I logo yang juga dibuat beberapa alternatif dengan sedikit perbedaan. Alternatif dibuat agar pilihan logo yang sesuai dengan identitas FKMPD terdekati dengan baik.

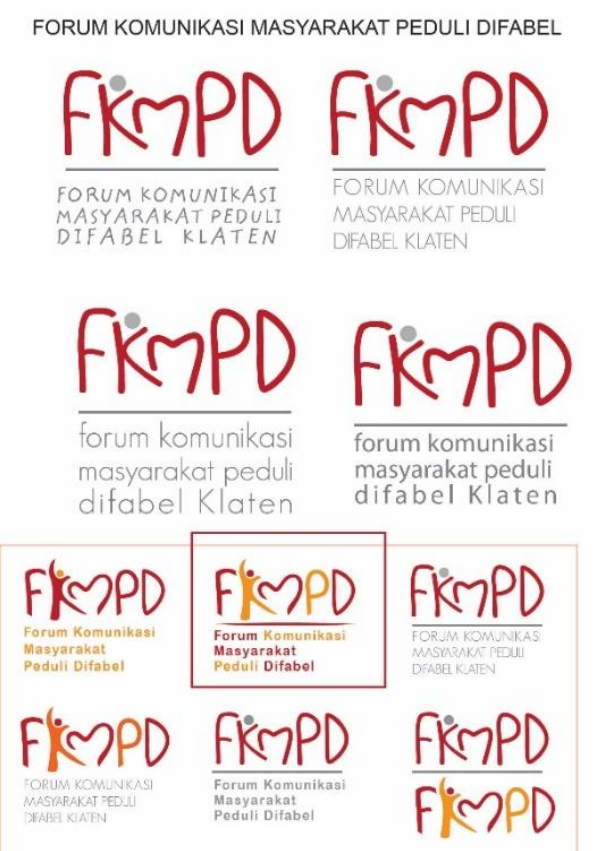

Gambar 5. Alternatif Logo yang dikonsultasikan kepada kelompok

7. Memberikan alternatif logo kepada mitra, lalu mitra memilih 1 logo final. Hal ini dilakukan agar tercapai kesepakatan dari brainstorming, tahap perancangan awal, dan hasil final sesuai dengan pandangan dan kesesuaian dari FKMPD dan pembuat logo.

8. Setelah logo final terpilih, kemudian membuat aplikasi logo ke dalam berbagai media.

\section{Hasil Perancangan}

1. Desain logo

Logo bertipe logotype (logo yang terdiri dari susunan huruf sesuai dengan nama entitasnya) untuk menekankan nama FKMPD agar menonjol, sebagai upaya untuk memperkenalkan logo baru. Logo mengandung ikon figur manusia pada huruf $\mathrm{K}$ pada FKMPD yang mengekspresikan rasa senang (bahagia) dan bersemangat yang merepresentasikan harapan kesetaraan difabel dengan non difabel. simbol hati yang terintegrasi dengan huruf $M$ di FKMPD merupakan representasi kepedulian. warna logo merah sesuai permintaan pihak FKMPD dan juga mengartikan semangat. Selain merah logo juga berwarna jingga yang masih keluarga warna merah dalam lingkaran warna yang bermakna optimism dan antusias.

Desain revisi yang ada merupakan permintaan FKMPD untuk membuat warna logo yang lebih terlihat ke huruf $\mathrm{K}$ dan $\mathrm{P}$ sehingga perubahan warna pada huruf dilakukan. Warna huruf "K" dan "P" yang semula jingga dimana Panjang gelombang warna jingga lebih pendek dibanding warna merah sehingga kurang kuat jika dibandingkan warna merah diubah menjadi warna hitam agar lebih terlihat menonjol. Begitupun warna huruf lainnya yakni "F", "M", dan "D" diubah menjadi jingga. Warna merah tidak diimplementasikan lagi melainkan warna jingga yang masih merupakan warna hangat keluarga merah sehingga dalam hal makna warna tidak berbeda secara signifikan dengan warna merah dimana jingga merepresentasikan optimisme. Dibawah ini makna warna jingga menurut colorphsycology.org dan Kate Smith seorang ahli warna (Color Expert): 


\section{Drange is fun, \\ flamboyant, dynamic and \\ radiates warmth. A close \\ relative to red, the energy \\ of orange is gentler and \\ more restrained. Orange \\ uplifts, gives confidence \\ and always injects fun. \\ Hensational}

Gambar 6. Makna warna jingga menurut ahli warna Kate Smith

Sumber: http://www.sensationalcolor.com/kate-

$$
\underline{\text { smith }}
$$

Secara konseptual tidak mengubah pemikiran dan landasan pergerakan dari FKMPD untuk membuat setara. Desain logo yang sesuai dengan visi-misi FKMPD memberikan semangat baru untuk FKMPD tingkat Kabupaten untuk terus melakukan advokasiadvokasinya secara aktif.

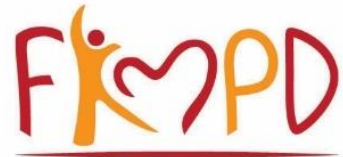

Forum Komunikasi Masyarakat Peduli Difabel

Gambar 7. Desain logo final

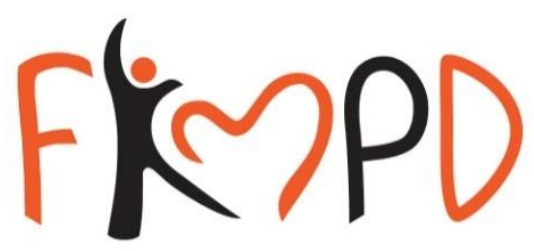

Gambar 8. Desain logo final hasil revisi oleh FKMPD dengan adanya perbedaan warna

2. Implementasi logo pada media

Gaya grafis khas diambil dari bagian bentuk logo yakni simbol hati pada huruf $\mathrm{M}$ dan ikon figur manusia pada huruf K. warna khas logo yaitu jingga dan hitam dimplementasikan pada berbagai media yang diperlukan FMKPD Klaten secara konsisten sebagai berikut:
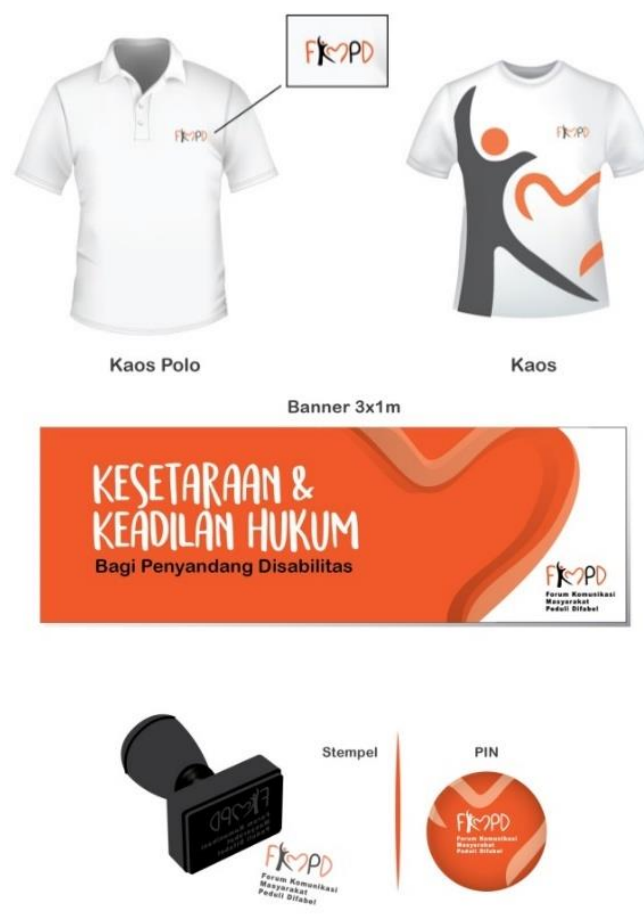

Gambar 9. Aplikasi dalam Media Promosi dari Logo FKMPD

Identitas gaya grafis dimunculkan dalam media-media aplikasi FKMPD guna membentuk persepsi yang mencerminkan FKMPD itu sendiri. Hal ini juga dilakukan agar brand yang dibentuk mencerminkan kesesuaian identitas FKMPD itu sendiri.

Penjagaan konsistensi brand, harus dilakukan agar logo yang telah dibuat tidak hanya sebagai syarat administratif, namun juga terbentuk karena memang telah mencerminkan FKMPD itu sendiri. Harapan untuk dapat menjadi organisasi yang dapat memperjuangkan hak-hak difabel di wilayah Kabupaten Klaten juga menjadi harapan bersama antara FKMPD ataupun masyarakat Klaten, agar tercipta Klaten ramah difabel, Klaten tidak diskriminatif, dan akhirnya tercipta Klaten Inklusif, dimana seperti organisasi-organisasi 
difabel di dunia sesuai dengan UNCRPD.

\section{SIMPULAN}

Kebutuhan komunikasi visual sebetulnya sangat penting untuk segera menjadi perhatian bagi organisasiorganisasi difabel di desa. Dimana komunikasi visual sebagai bagian dari penyebaran informasi, identitas dan citra, terutama logo yang menjadi point utama dalam pengenalan identitas terhadap masyarakat. Logo merupakan awal untuk membentuk persepsi masyarakat secara umum dalam melihat difabel sebagai sebuah subyek yang sama dengan nondifabel lain. Perjuangan untuk mencapai kesetaraan juga harus didampingi dengan pembentukan citra yang positif oleh orang-orang yang peduli dengan difabel.

Dalam mendesain identitas visual berupa logo bagi organisasi difabel tidak harus menggunakan elemen simbol difabel melainkan ikon dan simbol yang merepresentasikan semangat dan kepedulian untuk menyetarakan difabel. Dalam usaha mendukung advokasi penyetaraan difabel dengan non difabel, Secara visual penggunaan ikon dan simbol yang justru bukan simbol difabel menunjukkan bahwa difabel dapat setara dengan yang lainnya.

Isu Perempuan dan Anak masih belum terlalu dikenal dalam masyarakat difabel itu sendiri. Kebutuhan kerjasama berikutnya dapat memberikan sedikit bantuan dalam hal penyampaian pesan komunikasi visual tentang isu yang sedang diangkat oleh FKMPD Klaten. Hari Disabilitas Internasional merupakan waktu yang tepat untuk dapat menggali ide serta konsep-konsep kesetaraan, terutama penggunaan logo ini, agar komunikasi visual dapat dijalankan dengan baik.

\section{DAFTAR PUSTAKA}

Bonardo, M. A. (2015). Komodifikasi disabilitas sebagai tayangan populer di televisi. Masters thesis, Postgraduate Program in Communication Studies.

Cenadi, C. S. (1999). Elemen-elemen dalam desain komunikasi visual. Nirmana, 1(1).

Farhana, M. (2012) Brand elements lead to brand equity: Differentiate or die. Information Management and Business Review, 4(4), 223-233.

Hardy, G. (2011). Smashing logo design: The art of creating visual identities. Chichester, John Willey and Sons Ltd.

Kirk, L. (2013). Visual branding in graphic design. (honors theses). University of Southern Missisippi.

Listya, A. (2016). Bukan sekedar hiasan: gaya grafis khas sebagai identitas visual korporat. Jurnal Desain, 3(02), 107-117.

Van den Bosch, A. L., De Jong, M. D., \& Elving, W. J. (2006). Managing corporate visual identity: Exploring the differences between manufacturing and service, and profit-making and nonprofit organizations. The Journal of Business Communication (1973), 43(2), 138-157.

\section{Saduran Daring}

https://pbs.twimg.com/profile_images/57 3044441771995136/Za31vmam.j peg 
https://komunita.id/wp-

content/uploads/2016/09/Logo_O

HANA-300x300-300x300.jpg

https://www.solider.or.id/sites/default/fil es/logo_sigab.png

https://komunita.id/wpcontent/uploads/2017/01/GERK ATIN-Semarang-420x300.jpg https://4.bp.blogspot.com/OcolQgUGqH8/V61vJ4dTBaI/A AAAAAAAC_U/if9Tajp4Jzs9w havEYsPuBAvxtnJlpMQCPcB/s1600/LOGO\%2B SEHATI.png 